\title{
Mass Tree Mortality, Fuels, and Fire: A Guide for Sierra Nevada Forest Landowners
}

\section{DEVIN MCMAHON,}

Graduate Public Service Fellow in the Department of Earth System Science at Stanford University;

JODI AXELSON, Assistant Cooperative Extension Specialist in Forest Health at UC Berkeley;

SUSIE KOCHER, Forestry and Natural Resources Advisor at UC Cooperative Extension-Central Sierra, South Lake Tahoe, California
Tree mortality is changing California's landscape and affecting the amount and type of fuel available for wildland fires. Since the extraordinary drought of 2012 through 2015, millions of trees have died in California, particularly in the Sierra Nevada. Over the same period, fires have devastated towns and communities at forest edges, heightening concerns about future fires and the risks they pose to forests and people. Risk posed by fire depends on multiple factors, including weather and ignition sources, which are not affected by tree mortality. However, in areas that have experienced mass tree mortality, the amount and distribution of dead wood that can act as fuel has changed, altering the risk posed by fires. (See appendix A, a glossary, for definitions of terms that appears in bold.) This guide summarizes current research on the links among tree mortality, fuels, and fire risk. It identifies resources that can help landowners and managers take appropriate action to manage fuels. In addition, it discusses examples of mass tree mortality and assesses mortality's impacts on fuels-so that landowners and managers can understand fire risk on their own property and develop strategies to reduce it.

\section{TREE MORTALITY IN THE PAST, PRESENT, AND FUTURE}

\section{Background tree mortality rates}

Standing dead trees (known as snags), along with logs on the forest floor, are an important part of the forest landscape. Snags provide habitat for species such as cavity-nesting birds as well as wood-boring insects and their predators. Logs slowly release carbon and nutrients back into the soil as they decompose.

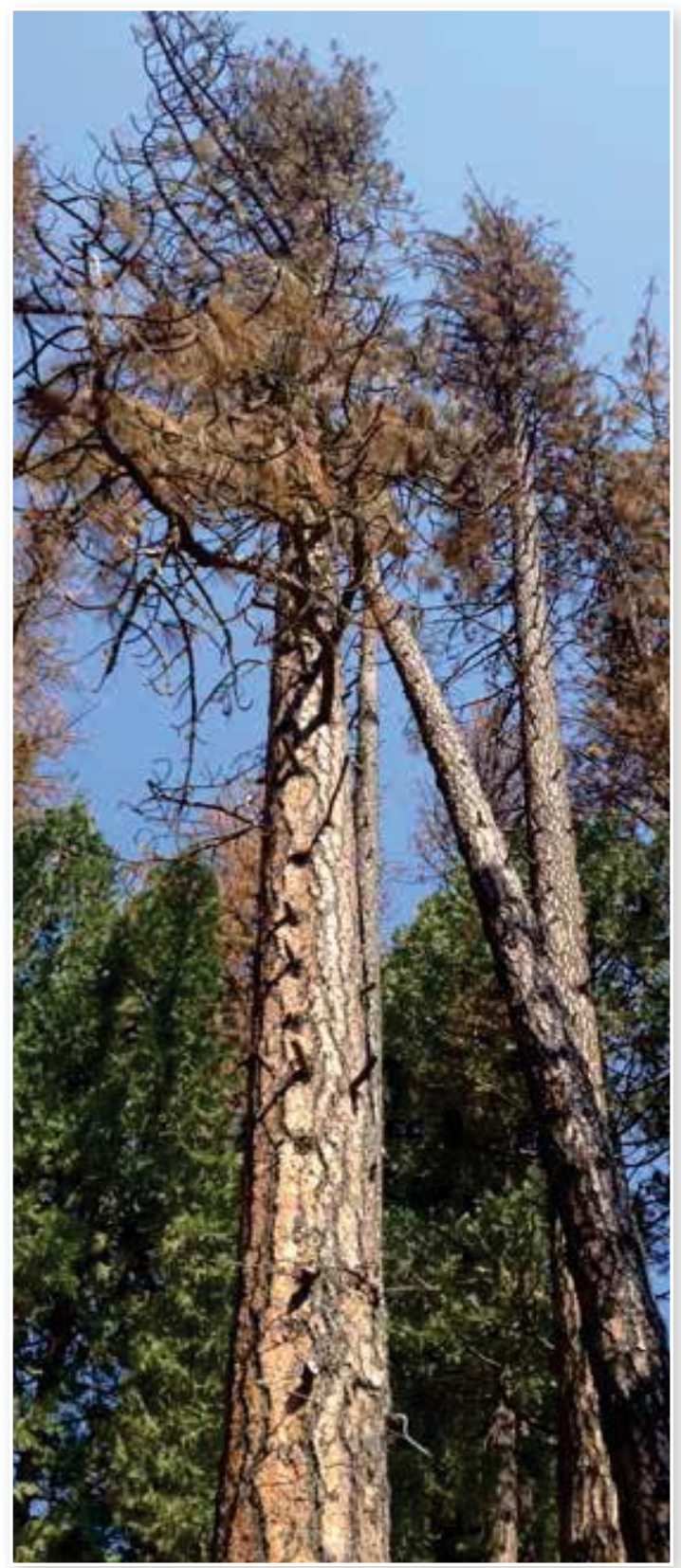


In the absence of disturbances that kill many trees at once-such as severe fires, droughts, and insect outbreaks-trees in mature forests generally die at low rates. This background mortality is caused by pathogens and insects, breakage by wind or other falling trees, and competition for light and water (Das et al. 2016). Background mortality kills about 0.5 to 2 percent of the trees in mature Sierra Nevada conifer forests each year, depending on the environment and the species present (Ansley and Battles 1998; Das et al. 2016; Fettig et al. 2010; van Mantgem et al. 2009).

Over the last four decades, tree mortality rates have increased across the western United States. In twenty old-growth forests across California, the background mortality rate among trees greater than 6 inches in diameter increased from 0.9 percent per year in the 1980s to 1.7 percent per year in the 2000s (van Mantgem et al. 2009). Regional warming, which increases water stress even in nondrought years-and which can benefit insects and other organisms that attack trees-appears to be a primary cause of this increase in background tree mortality.

\section{Mass tree mortality}

Even as background mortality has increased, severe drought has triggered mass tree die-offs in the last decade. Conservative estimates of tree mortality derived from aerial detection surveys-conducted by the U.S. Forest Service's Forest Health Protection program-indicate that more than 142 million trees died in California between 2012 and 2018, constituting the worst example in recorded history of a tree die-off mediated by drought and insects (Moore et al. 2019). Nearly 1.5 percent of California's approximately 10.1 billion trees perished during the die-off, although the mortality was concentrated within certain areas of the state, particularly the Sierra Nevada (Christensen et al. 2018).

Mortality patterns during the die-off varied with land management practices-drought-and insect-driven mortality rates in the Sierra Nevada were 50 percent higher in national forests than on private land (Christensen et al. 2018). On private industrial lands, most dead trees were removed quickly throughout the tree mortality event. Barriers to removing dead trees in national forests and on small, privately owned parcels include shortages of funds, labor, and markets for the wood, as well as other values of dead trees, such as wildlife habitat. Premortality differences in the density of stands and other management effects may also have affected mortality rates (as discussed below).

A recent study found that, in 180 especially vulnerable, pine-dominated plots in national forests from the central to the southern Sierra Nevada, 49 percent of trees died between 2014 and 2017 (Fettig et al. 2019). In another inventory of more than 280 plots at eight sites-spanning a north-south gradient, and encompassing various Sierra Nevada forest types and ownership arrangements-average mortality was 17 percent (Axelson et al. 2018; Axelson et al. 2019). Although local mortality varies, this mass die-off has greatly increased the number of dead trees on the landscape (fig. 1).

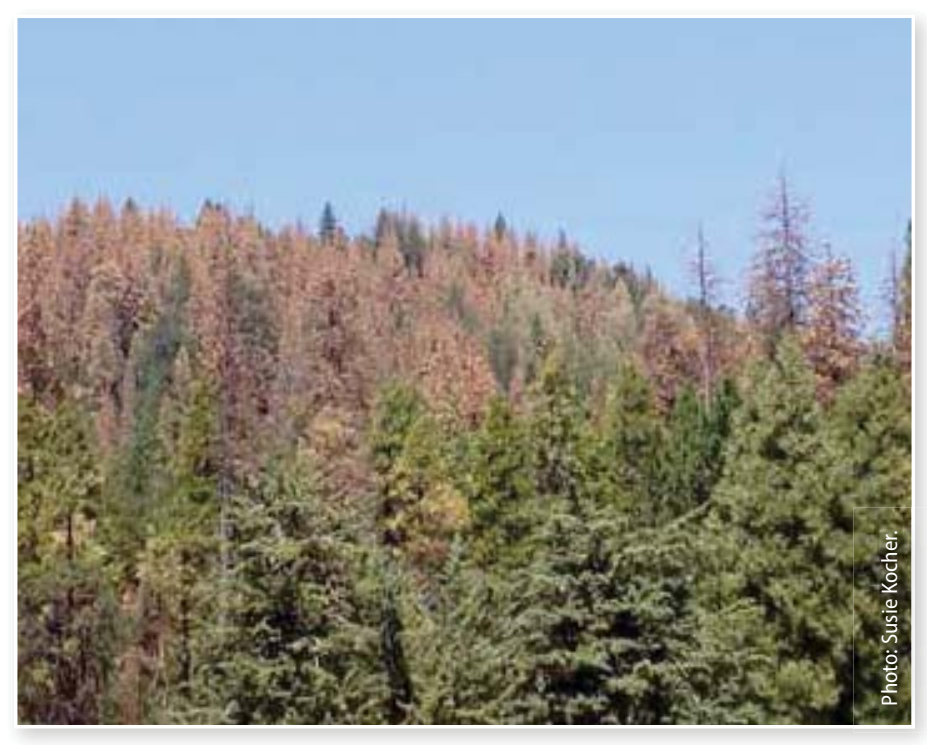

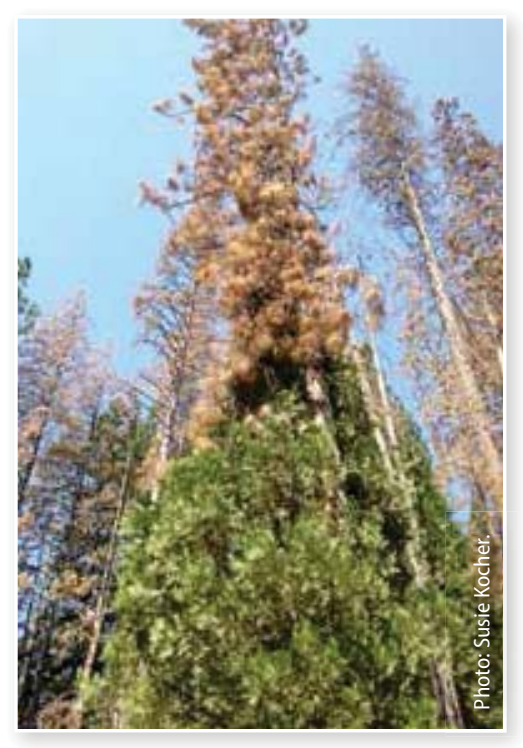

Figure 1. A hillside outside Yosemite National Park in August 2016. Most ponderosa pines on the site died, while most cedars below them are still alive. 


\section{Tree mortality patterns}

Tree mortality in the recent drought varied with latitude, elevation, soil depth, and species. Mortality tended to increase from north to south in the Sierra Nevada. At eight sites surveyed by Axelson et al. (2018) - from the Plumas National Forest in the north to Mountain Home Demonstration State Forest in the south-mortality between 2012 and 2016 ranged from 3 percent to 42 percent of trees. Mortality was also greater at lower elevations, on shallower soils, and on drier southwest- and west-facing slopes (Fettig et al. 2019; Paz-Kagan et al. 2017). As one might expect, more trees died at hotter and drier sites, where lack of water was especially stressful and where trees were highly vulnerable to attack by bark beetles (Young et al. 2017). In some cases, a larger proportion of trees died in denser stands, where more trees per acre competed for limited water supplies. At the driest sites, however, drought stress killed similar proportions of trees in high-density and low-density stands, possibly because there was not enough water to support even a few trees (Fettig et al. 2019; Young et al. 2017).

Pines were hit especially hard, with nearly twice as much mortality in pine-dominated areas in a study of old-growth stands in Sequoia National Park (Stephenson et al. 2019). In addition, it was the larger pines-which historically have survived fires due to their thick bark - that were more likely to die (Axelson et al. 2018; Fettig et al. 2019; Pile et al. 2018). Firs, most commonly white firs (Abies concolor), also suffered substantial mortality, while oaks generally survived the drought.

Multiple stressors combined to kill trees during and after the drought. In the Sierra Nevada, bark beetles were responsible for a large proportion of tree deaths. Hot, dry conditions weaken trees' defenses against beetles-for example, by reducing the flows of carbon and water that trees need to make sticky resins. In the study mentioned above, Axelson et al. (2018) found that beetle attacks caused more than 50 percent of the tree mortality at five of the eight sites in the Sierra Nevada-and up to 74 percent of the mortality at one fir-dominated site. Fir engraver beetle (Scolytus ventralis) was the most common culprit across the sites, although mountain pine beetle (Dendroctonus ponderosae) and western pine beetle (D. brevicornis) were the primary causes of mortality in pines (Fettig et al. 2019). Pine beetles prefer large trees-and once a beetle epidemic has started, beetles will attack healthy trees as well as those already exhibiting stress. Firs, meanwhile, regardless of their size, are more likely to be killed by beetles if they are already stressed (Stephenson et al. 2019). In the absence of epidemic beetle attacks, tree vigor can decline due to dehydration, as water-conducting tissues are damaged, or trees can conserve water by ceasing to take up carbon and ultimately "starve." Such trees may die after a drought has ended because they are unable to restore their growth rates and their defenses against insects and pathogens (Allen et al. 2010).

\section{Future tree mortality trends}

Throughout the twenty-first century, warming temperatures will worsen drought stress on trees. When the air is warmer, plants lose more water through their leaves, increasing drought stress even under normal precipitation and soil moisture conditions. In addition, drought-stressed trees are more vulnerable to insects and pathogens. Climate-driven shifts in the life cycles and ranges of trees, pests, and pathogens may also increase trees' vulnerability even without taking into account drought and temperature stress, as trees are exposed to new or increasingly abundant pests and pathogens (Stephenson et al. 2019). As temperatures continue to rise, therefore, both background and epidemic tree mortality rates are expected to increase (Allen et al. 2015). With multiple stressors present in a system, tree health declines as if going down a funnel. The farther down the funnel the tree goes, the more likely the tree is to die-even from causes that would not normally be lethal (Axelson et al. 2019).

\section{LIVING AND DEAD VEGETATION AS FUEL FOR FIRE}

\section{Fire effects}

Vegetation, living or dead, can fuel wildfires, and the type, density, and structure of vegetation can determine how fires burn and how much damage they cause. Tree mortality and fuel loads (the amount of live or dead vegetation on the landscape) affect multiple aspects of fire:

- Behavior is the way in which fire spreads through vegetation and across the landscape. Components of fire behavior include the speed and direction of fire spread, how long the fire continues to burn in an ignited area, and whether the fire stays on the 

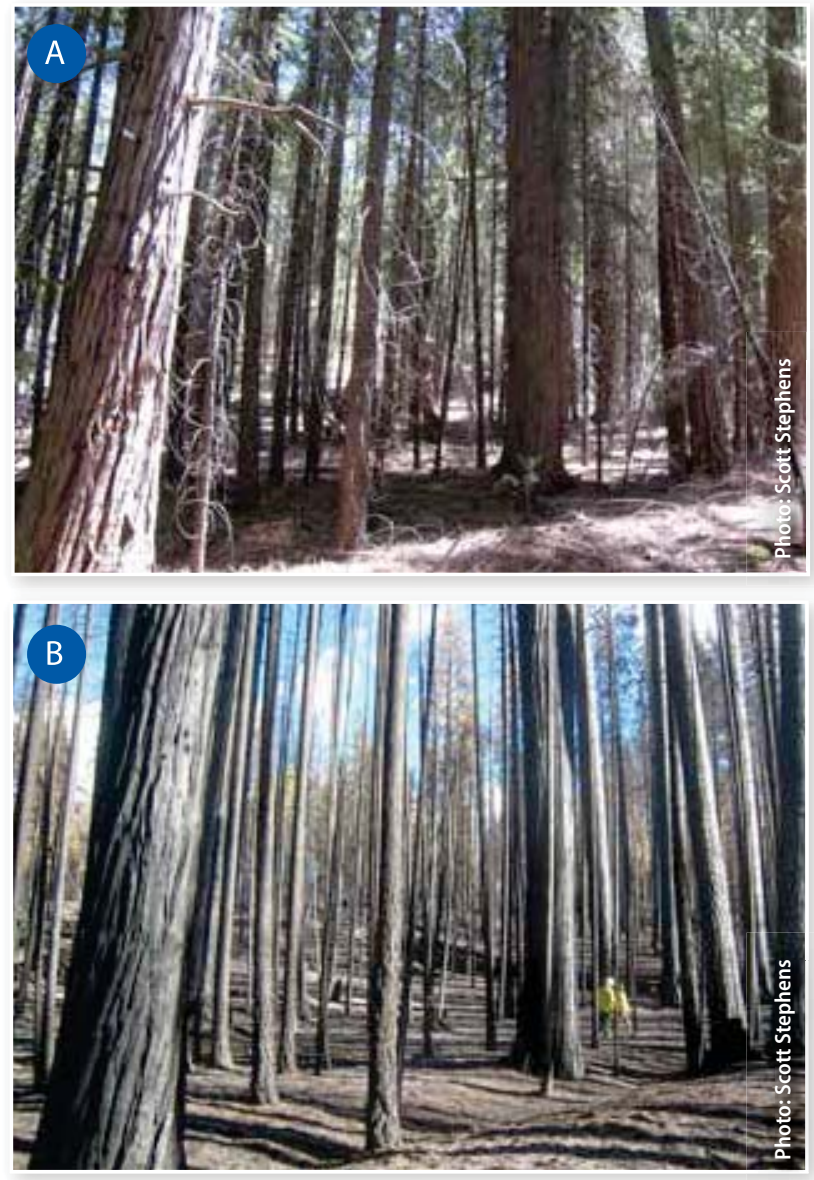

Figure 2. Before the Rim Fire, this stand was dense, with high understory fuel loads and many small trees $(A)$. The fire burned the stand at high severity, killing all trees, consuming the forest floor, and damaging the soil (B).

ground or reaches into tree canopies.

- Intensity is the amount of heat released by the fire, often measured by flame height. More fuel and drier fuel conditions will lead to fires of greater intensity.

Severity concerns how much live vegetation is burned, which determines the ecosystem impacts of the fire (Keeley 2009). High-severity fire in a forest kills most if not all trees, independent of their size (fig. 2), while a low-severity fire kills mainly smaller trees and few, if any, large trees. Fires of similar intensity (giving off the same amount of heat) can affect plants differently based on the plants' defenses against fire, such as bark thickness or resprouting ability (fig. $3)$. Effects also depend on the health of trees, including the amount of moisture trees contain, which affects their ability to recover from fire damage.

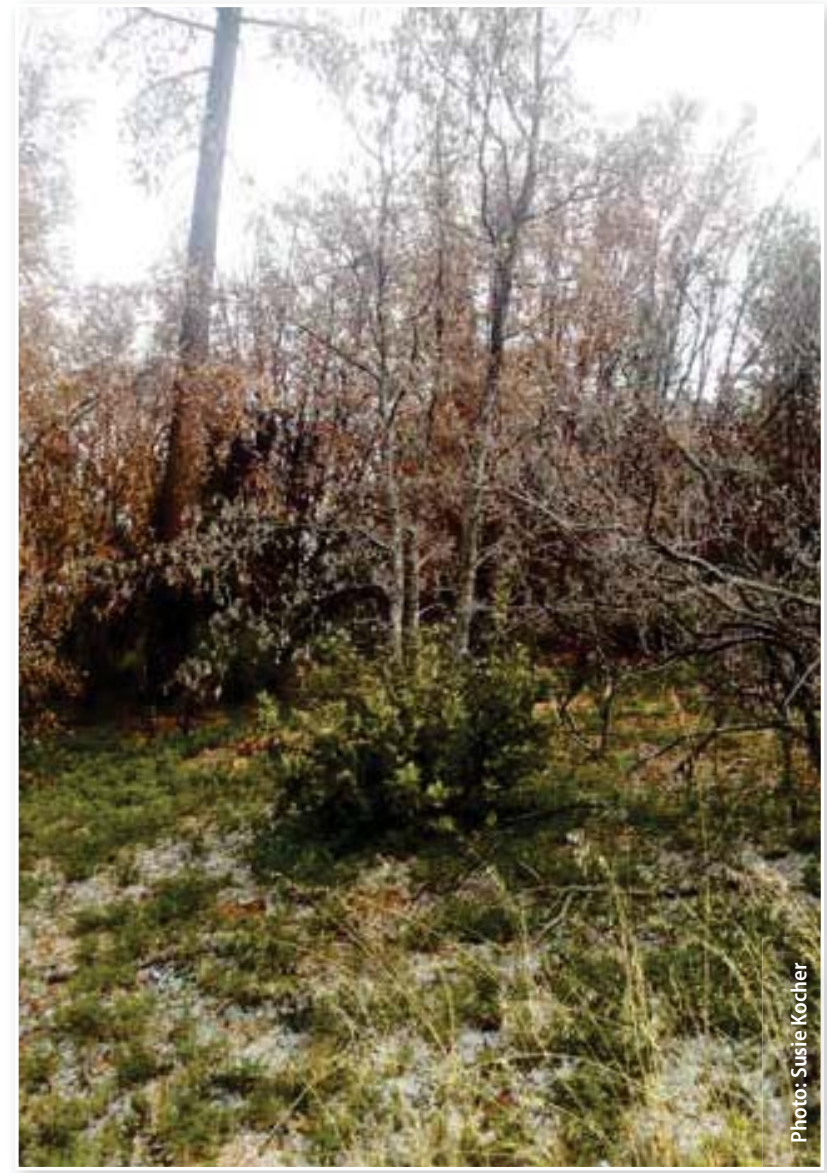

Figure 3. Conifers were killed by a moderate-severity fire near Yosemite National Park, while oaks with scorched foliage are resprouting from their bases about a year afterward; grass and shrubs have also regrown.

\section{Distribution of fuels}

The behavior, intensity, and severity of a fire depend on how fuel is clustered on and above the ground. Greater quantities of surface fuels, on or near the ground, increase the probability that a fire will burn hot enough to damage the stems and roots of living trees, or to scorch and kill their needles. Flames from high-intensity surface fires may also reach high enough to ignite tree crowns, leading to torching-in which the whole crown is burned. Crown fires become more likely if flames can climb from the ground to the base of the live crown via ladder fuels such as dead branches, shrubs, and small live or dead trees (Agee and Skinner 2005; Jenkins et al. 2012). Unlike surface fires, crown fires often kill mature trees, even fire-adapted species such as ponderosa, sugar, and Jeffrey pines. If crown fuels-tree canopies-are sufficiently dense, dry, and close together, 


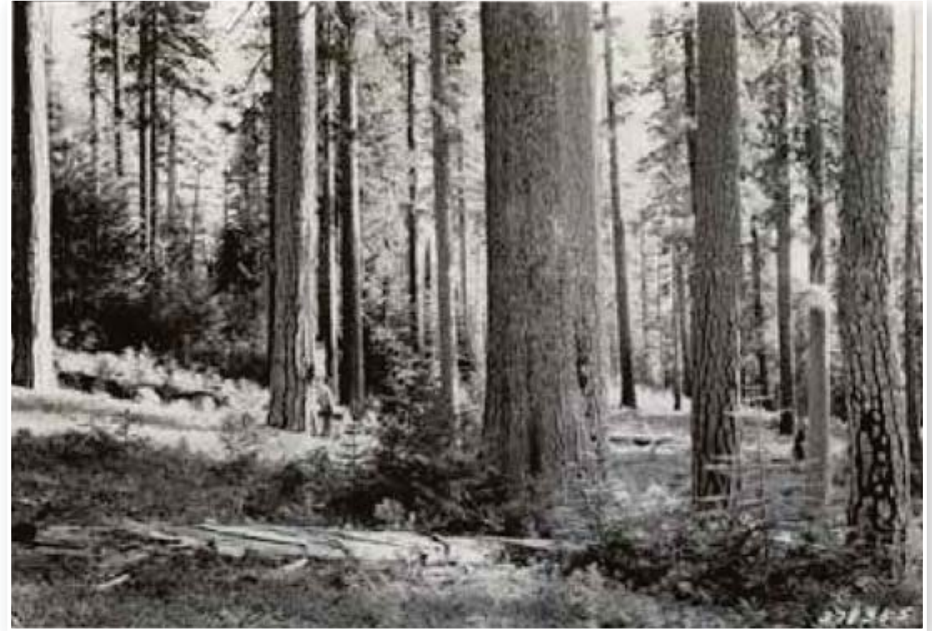

Figure 4. Ponderosa and sugar pine stand in El Dorado County in 1938. Frequent, low-severity fires would have maintained similarly open structure and sparse understory in many conifer ecosystems until fire suppression became an official, vigorously implemented policy.

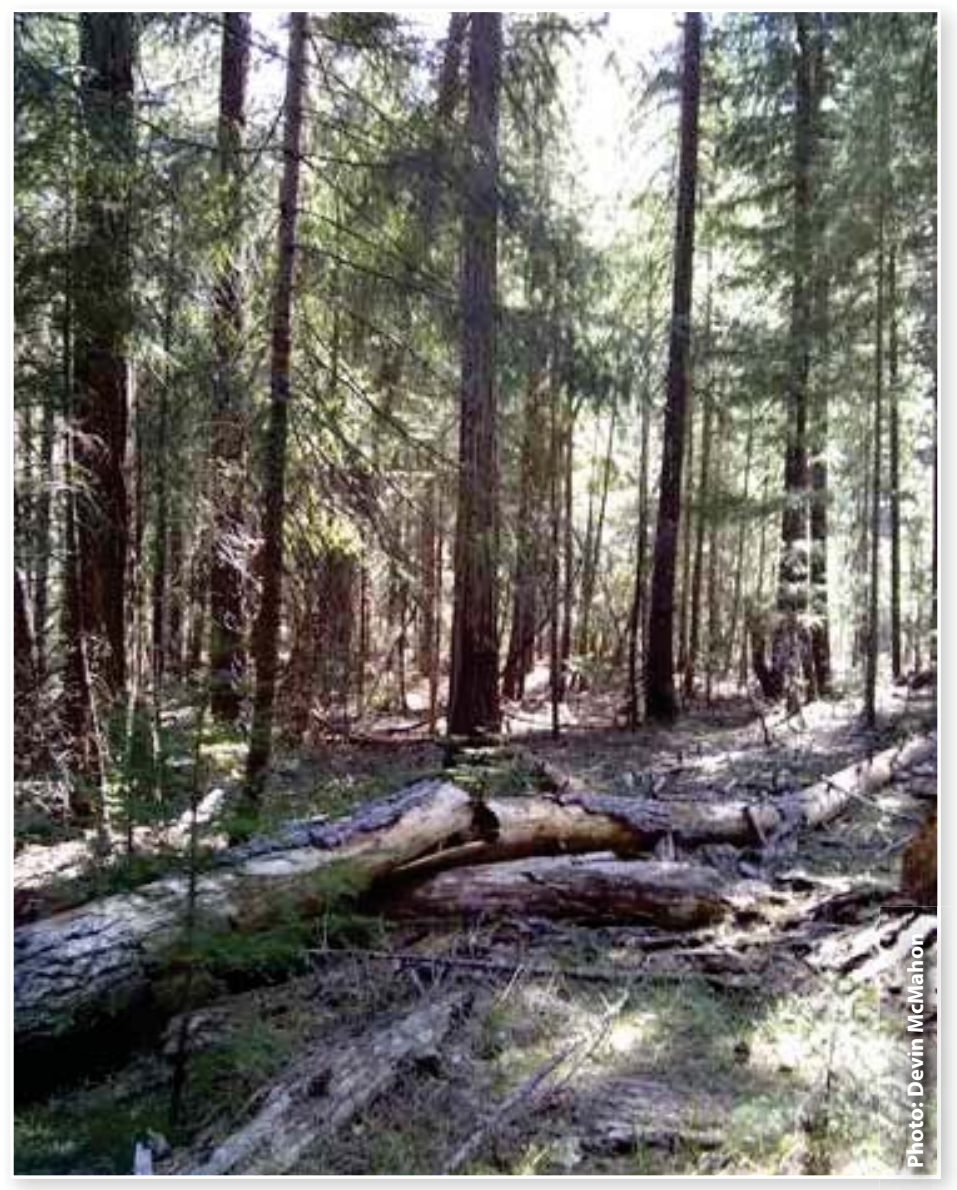

Figure 5. A modern, dense stand in Plumas National Forest, with many small trees that can, acting as ladders, carry fire into the canopy-as well as abundant surface fuels (dead branches and logs on the forest floor). crown fires can spread from tree to tree without touching the ground, making such fires unpredictable and difficult to control (Nunamaker et al. 2007). However, crown fires also require surface fuels to sustain their spread, and without enough surface fuels they will eventually drop back to the ground (Jenkins et al. 2012).

\section{Amount of fuel: A legacy of fire suppression}

Across much of California, forests are now more dense, with more trees and more fuel, than they were in the early 1900s, and may be more dense than they have been for centuries. Prior to Euro-American settlement, fires set by indigenous people, in addition to fires started by lightning strikes, periodically removed surface fuels and maintained more open forests, with large trees spaced farther apart from one another (fig. 4). Euro-American settlers initially set fires to clear land for agriculture and manage timber stands.

In the 1900s, however, California and the United States adopted policies of nearly total fire suppression in order to increase timber stocking and protect lives and property. This policy, along with advances in firefighting techniques, means that almost all fires in the last century were rapidly extinguished-except under the driest, windiest conditions, when suppression was not possible. Consequently, small trees and other fuels have accumulated over time if not consumed in severe fires (Nunamaker et al. 2007). The density of trees and the amount of fuel across much of California are outside the natural range of variation to which tree communities are adapted, possibly leading to larger and more intense fires than trees are equipped to withstand (Safford and Stevens 2017) (fig. 5).

Excessive forest density and fuel loads present problems throughout California, independent of recent tree mortality. Especially under dry and windy conditions, the difference between live and dead trees may be less important in determining fire severity than the overall amount of fuel (Agee and Skinner 2005). However, tree mortality can have important effects on fuels and fire, as discussed in the next sections. In addition, drought-related mass mortality is not likely to restore open, fire-resistant forest conditions. In pine forests, bark beetles tend to kill larger trees that would have survived fire, leaving small trees that will continue to form dense canopies and are less fire-resilient due to their thinner bark. 
The resulting tree mortality leads to increased fuel on the landscape for future fires. The interactions of multiple disturbances, such as drought and fire, play an important role in determining the health of future forests.

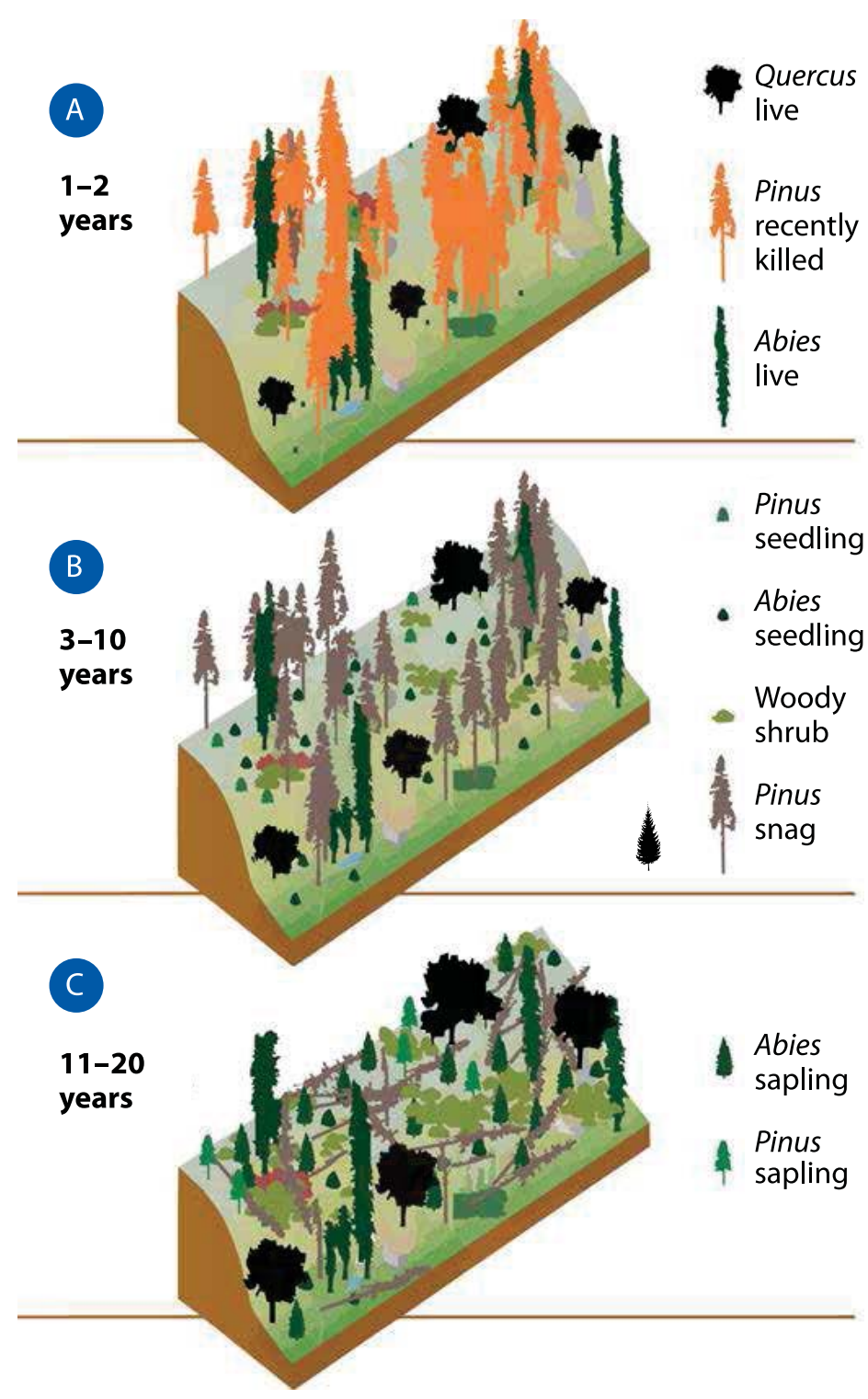

Figure 6. After a bark beetle outbreak, the needles of dead conifers turn red $(A)$ and then fall, leaving gray snags and contributing to surface fuels (B). Eventually the snags fall, leaving large fuel loads on the forest floor and opening space for understory vegetation to grow (C). Figure reproduced from Stephens et al. 2018, with permission.

\section{EFFECTS OF TREE MORTALITY ON FUELS AND FIRE SEVERITY}

\section{Increase in dead fuels}

Tree mortality directly increases the quantity of dead, dry, and therefore easily ignitable fuel on the landscape. As dead trees fall, fuel is redistributed from the canopy to the forest floor. Initially, dying trees retain their needles, which turn yellow and then red over the course of a year or two (fig. 6A). Dry, dead needles in the canopy increase the probability of crown fire ignition and spread (Jolly et al. 2012; Page et al. 2012). Within a few years, needles and twigs fall and become fine surface fuels, decreasing canopy flammability but potentially increasing surface fire intensity until they decay (Hicke et al. 2012; Preisler 2012; Jenkins et al. 2012) (fig. 6B).

Over the next decade, branches and whole snags fall, increasing surface and ladder fuel loads (Battles et al. 2015; Page and Jenkins 2007) (fig. 6C). Decaying wood breaks down into smaller and smaller pieces which, if ignited, can fly ahead of a moving fire. These embers can start additional fires, a process known as spotting (Stephens et al. 2018). Large logs on the forest floor can also burn at high temperatures and for long periods, heating the soil and killing roots even if the flames do not harm the aboveground parts of trees (Monsanto and Agee 2008).

When dead trees fall, they leave openings in the forest that allow in more sun, which dries out surface fuels and encourages the growth of understory vegetation. Shrubs and young trees can inhibit fire spread if they remain alive and moist (Nagel and Taylor 2005; Stephens et al. 2018), but they can also increase the amount of surface and ladder fuels and contribute to more intense fires (Bigler et al. 2005; Coppoletta et al. 2016). Dense growth of shrubs or grasses may also shade out tree seedlings (fig. 7). If the shrubs burn before trees have a chance to reestablish, the former forest may be permanently converted into a shrub-dominated system, in which fires may be less intense but more frequent (Walker et al. 2018). While shrublands are valuable ecosystems in their own right, this type conversion can have substantial impacts on ecosystem function and the values that landowners associate with forests. 


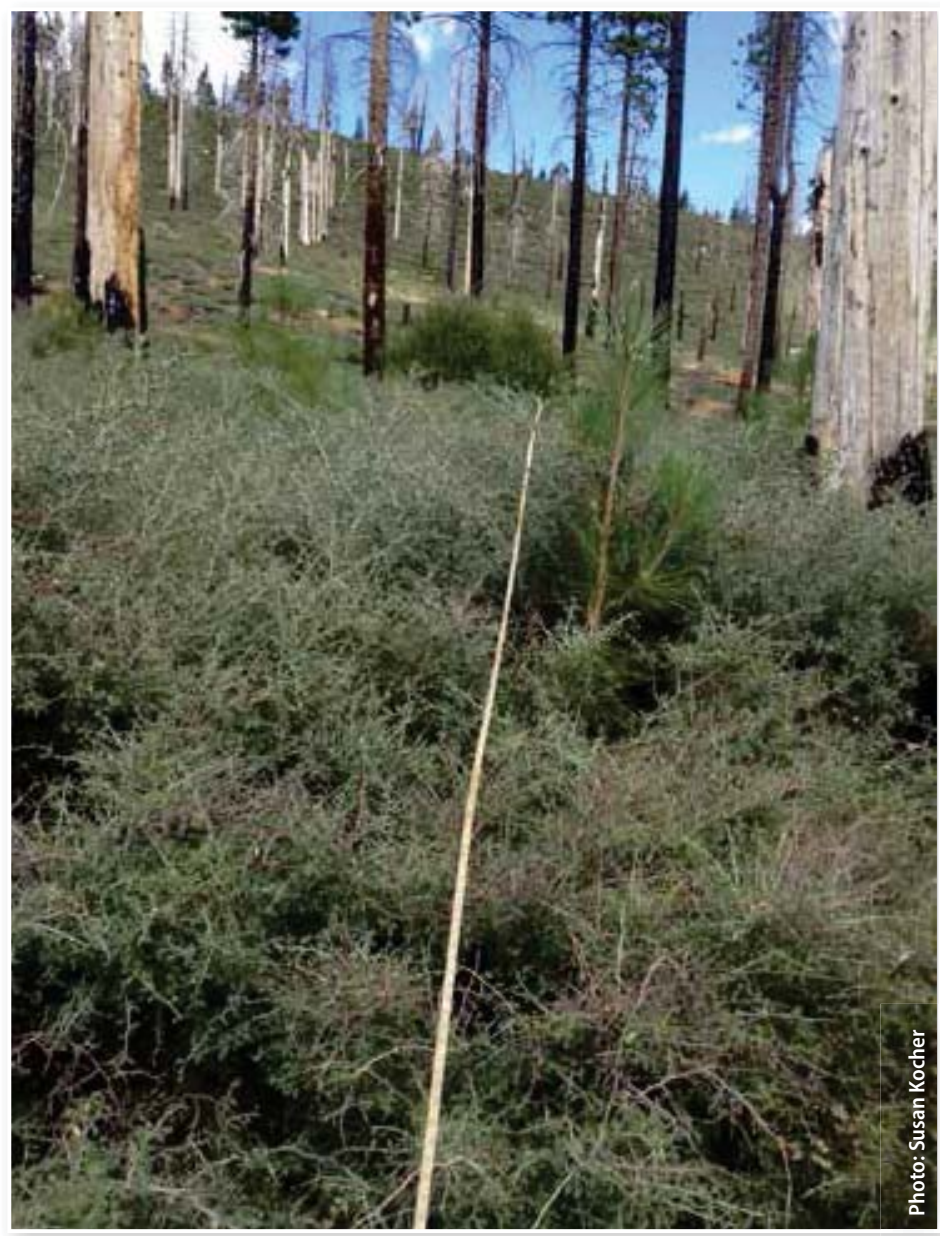

Figure 7. Dense shrubs can fill in the spaces between trees following severe fire, sometimes inhibiting new tree seedlings.

\section{Increased potential for mass fires}

Large continuous patches of coarse fuels (logs and snags) following high tree mortality have the potential to fuel mass fires that burn several square miles at once, creating self-reinforcing wind patterns and spotting. This phenomenon is very rare and not well understood, but is a major concern under weather and fuel conditions that are unprecedented in recent history (Stephens et al. 2018).

\section{Increased fire severity-but similar probability of burning}

Studies across western North America conducted after bark beetle outbreaks have found that, when dead trees were present, surface fuel loads eventually increased and fire intensity could increase-but that the probability of fire occurring in the first place generally did not increase in areas with dead trees compared to areas without tree die-off (Hart et al. 2015; Hicke et al. 2012). In the Sierra Nevada specifically, two studies found that increased density of snags increased fire severity. Even in areas with many snags, however, temperature, humidity, and the presence of shrubs to act as ladder fuels may be more important than dead fuel loads in determining fire intensity and severity (Coppoletta et al. 2016; Stephens et al. 2018). In addition, the stress of a drought or other mortality factors could also cause surviving trees to experience greater fire severity (more damage to trees and the ecosystem) for a given fire intensity (van Mantgem et al. 2018).

In some environments, tree mortality may not increase fire severity. In a Southern California study, tree mortality due to bark beetles did not increase fire severity, and in central Oregon, 8 to 15 years after a bark beetle outbreak, fire severity under the most extreme weather conditions was actually lower in stands with a larger proportion of beetle-killed trees (Agne et al. 2016; Bond et al. 2009).

In summary, tree mortality can affect fire behavior and may lead to more severe fire once a fire has started. However, tree mortality may not be the main factor that controls fire risk, and does not always increase fire severity. After tree mortality, managing both dead and living trees can reduce risk from fire.

\section{FUELS: ONE COMPONENT OF RISK FROM FIRE}

\section{Fuels' lack of influence on probability that a fire will start}

Although fuel is a necessary condition for wildfire, weather, topography, and vegetation structure also affect fire behavior, intensity, and severity-and of course, any fire requires an ignition source. High fuel loads do not change the probability of ignition, which often depends on human activities. In the Sierra Nevada, more than 93 percent of wildfires on lands monitored by the California Department of Forestry and Fire Protection (Cal Fire) between 1919 and 2016 were started by people, along with nearly half of fires on more remote U.S. Forest Service lands. The number of ignitions increased along with the human population through most of the twentieth century, but has declined since the 1980s due to a combination of awareness, policy, and urbanization of previously forested land (Keeley and Syphard 2018). 


\section{Understanding fire risk}

For wildland fire specialists, the term fire risk refers specifically to the probability that a fire will start in a given place; it does not depend on prior tree mortality or fuels (Hardy 2005). Landowners and managers who wish to develop a strategy to manage fire risk, however, may be more interested in a broader definition of risk (table 1). In this context, the risk posed by fire is a combination of the probability that fire will occur and the expected effect of fire on something of value, such as a house or a forest with many ecological functions (Finney 2005). The effect of fire can be regarded as the combination of the behavior and intensity of the fire, based on the fuel present, and the vulnerability of the asset at risk (Scott et al. 2013). For example, a tree with thick bark and without low branches is less vulnerable to fire, while a bare-soil fire break and a hardened roof can protect a house. Fuel management can alter fire behavior to reduce overall risk, while other actions can reduce risk by decreasing vulnerability to fire and increasing the ability to recover.

Table 1. Factors that contribute to overall risk from fire. External factors cannot be managed by private landowners or management agencies, while internal factors can be mitigated with sufficient resources and expertise. Components of risk that are affected by prior tree mortality are shown in italics.

\begin{tabular}{|c|c|c|c|}
\hline Component of fire risk & External factors & Factors that can be mitigated & Example mitigation actions \\
\hline fuel continuity & $\begin{array}{l}\text { - topographic variation } \\
\text { - location of roads, streams, and } \\
\text { structures }\end{array}$ & $\begin{array}{l}\text { - tree spacing } \\
\text { - } \text { amount of ladder fuel }\end{array}$ & $\begin{array}{l}\text { - thinning to create fuel breaks } \\
\text { - thinning or mastication of } \\
\text { ladder fuel } \\
\text { - piling fuels (although unburned } \\
\text { piles can increase fire intensity) }\end{array}$ \\
\hline weather conditions & $\begin{array}{l}\text { - } \text { wind speed and direction } \\
\text { - temperature } \\
\text { - humidity } \\
\text { - precipitation }\end{array}$ & none & none \\
\hline
\end{tabular}




\section{Measuring fuel loads to assess fire risk}

Fuels are usually distributed unevenly on the landscape, which can make it difficult to accurately predict how a fire will spread under particular weather conditions. However, quantifying fuel loads can help estimate the potential behavior and effects of a fire. In one common method, called the planar intercept method, fuels are quantified by counting the pieces of dead wood that intersect a straight line (or transect) along the ground, or the imaginary plane extending vertically 6 feet above that line (Brown 1974) (fig. 8). Collecting data from many transects across a landscape can provide quantitative estimates of fuel loads, which can then be used in a fire model to predict fire behavior and fire severity on that landscape. Another method, less precise, is to visually compare the density of trees, shrubs, and woody debris with photos corresponding to quantified fuel loads in the same forest type, as in the Natural Fuel Photo Series produced by the U.S. Forest Service (see appendix B, which discusses resources for landowners). Photo comparisons (figs. 9 and 10) allow landowners to gain an intuitive sense of the fuel loads on their land without performing laborintensive data collection.

Because fuel loads can be very different across even a few acres, landowners who want to assess fuel loads on their property will need to perform assessments in multiple locations. For example, a grid can be laid over a map of the landscape, and measurements taken in each cell, with more measurements needed in more complex terrain. Alternately, a computer algorithm can be used to evenly spread a given number of sampling points over a map, with the number of points chosen based on the time and resources available. Fuel load estimates can be used to identify areas of a property that are the highest priority for fuel treatment. Several resources are available to help landowners determine how and where to collect information on fuel loads in order to accurately represent the property, including registered professional foresters, Cal Fire officials, and defensible space programs (see appendix B).

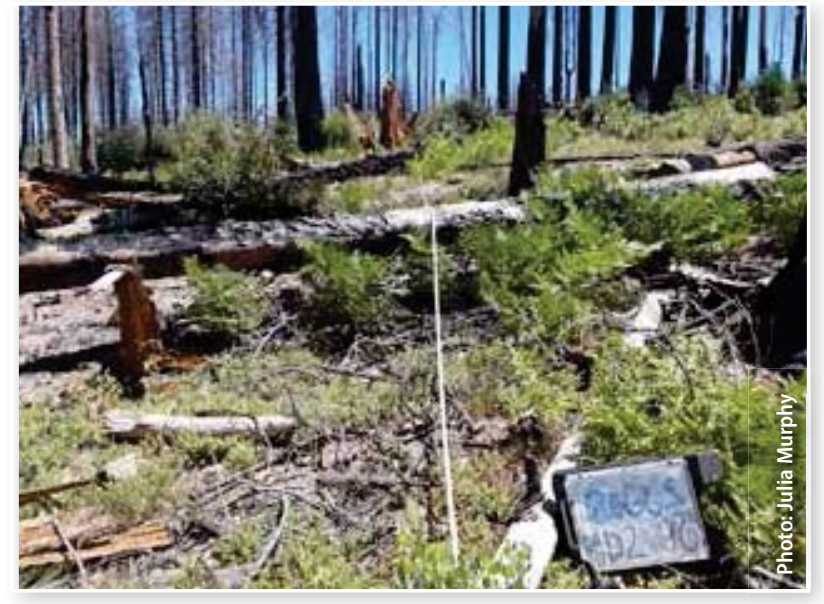

Figure 8. A transect measured surface fuels in 2018 at Boggs Mountain State Demonstration Forest, which was severely burned in the Valley Fire in 2015.

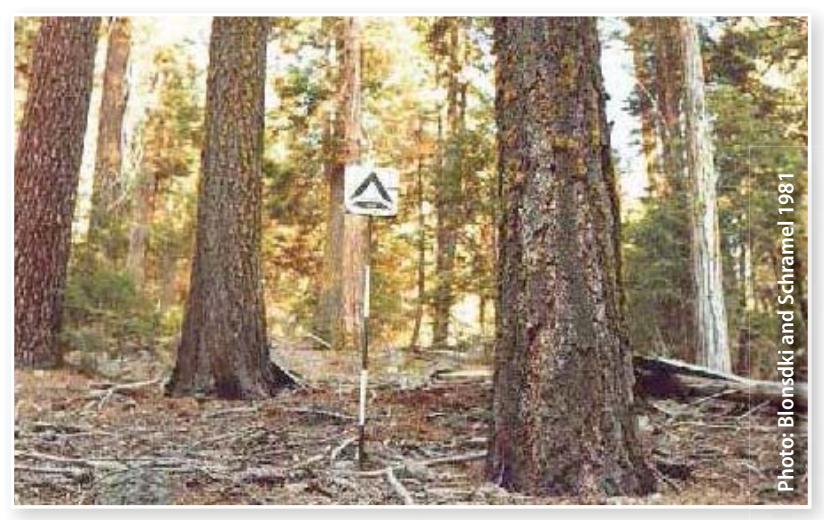

Figure 9. This white fir stand has 14.6 tons per acre of surface fuels, including 8.2 tons per acre of fine fuels (fuels less than 3 inches diameter, but not including litter). The high fuel load may cause this stand to burn with high severity in a wildland fire.

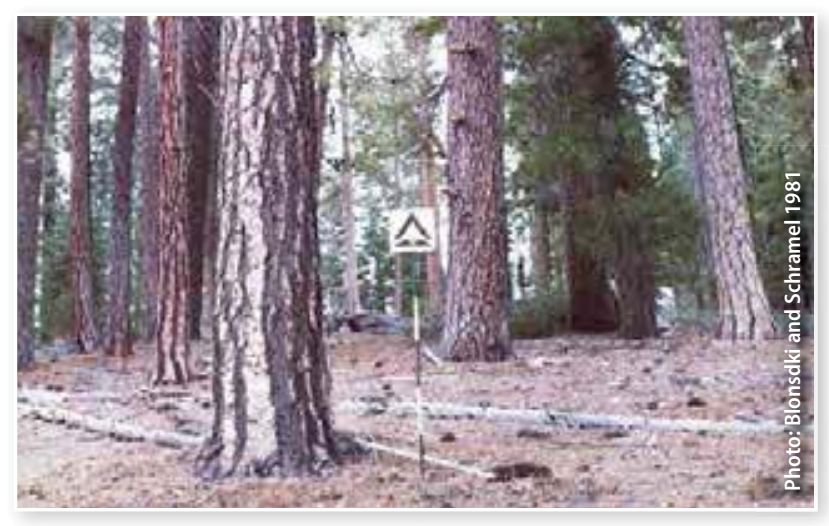

Figure 10. This mixed-conifer stand has 3.9 tons per acre of surface fuels (not including litter) - a low fuel load consistent with low fire severity. 
Fuel size classes. Assessing the quantity of dead material by size class is a common way of characterizing the fuel load because the size (diameter) of wood pieces determines how easy it is for the fuel to ignite. The smaller the size of the fuel-that is, the higher the ratio of surface area to mass-the more quickly it can lose moisture during dry weather and become vulnerable to ignition.

Fuels are classified by the amount of time it takes for their internal water content to respond to changing atmospheric moisture conditions. For example, small branches between 0.25 and 1 inch in diameter are classified as 10 -hour fuels, meaning that it takes around 10 hours for the moisture content of two-thirds of the fuel to come into equilibrium with atmospheric moisture. Table 2 shows dead fuel classifications used in calculations of fire risk (Lutes et al. 2006). Logs more than 8 inches in diameter may only become flammable after months of dry conditions-and once they are dry, they take a similarly long time to regain moisture. If ignited, dry logs can fuel extreme fire intensity and can smolder for weeks to months, damaging roots and soil around them and hindering efforts to control a fire (Monsanto and Agee 2008).

Fuel moisture. The higher the moisture content in fuel, the more difficult it is to ignite the fuel and the more energy is needed to evaporate water before the fuel can burn. Therefore, higher moisture content in fuel reduces fire intensity and spread. Moisture content of a given size class of fuel can be estimated based on the temperature, day length, moisture, and precipitation conditions over the time periods necessary for those fuels to dry. Current fuel moisture levels for 10-hour fuels can be estimated from weather stations. Fuel moisture content is commonly described as a percentage of the fuel's dry weight (that is, with all water excluded). Living plant tissues (leaves and wood) often have moisture contents greater than 100 percent of their dry weight-although the proportion can be as low as 50 percent for shrub species in arid environments. Risk from fire can be estimated by combining fuel moisture information with estimates of ignition probability, fuel loads, and temperature and wind conditions. Coarse-scale maps of current fire danger classes are available from the Wildland Fire Assessment System of the U.S. Forest Service (see appendix B).

High fuel loads. As a rough guideline, forests in the Sierra Nevada are at heightened risk of intense fire if surface loads of fine fuels - fuels with a diameter of 3 inches or less, along with litter-exceed 10 tons per acre (Scott Stephens and Brandon Collins, personal communication). These fuel conditions are common: at eight of eight sites in the Sierra Nevada, spanning species distributions and management types, average fine fuel plus litter loads ranged from 9 to 19 tons per acre, with litter accounting for the majority of fine fuels (Axelson et al. 2018). Taylor et al. (2014) estimated that, prior to fire suppression, fine surface fuels ranged from 5 to 8 tons per acre in the Lake Tahoe Basin.

Though assessing fine fuels can help prioritize fuel treatments such as prescribed fire, larger fuels such as dead trees also determine fire risk. It can be difficult to measure ladder fuels and estimate the effects of 1,000-hour fuels on fire behavior (Jenkins et al. 2012). Consequently, management of fine surface fuels may not be adequate to avoid uncharacteristic wildfires, or fires that are more severe than the most severe fires to which a forest type is adapted (Hardy 2005). Total surface fuel loads (with all fuel size

Table 2. Fuel classifications and characteristics.

\begin{tabular}{|l|l|l|}
\hline Fuel classifications & Diameter (inches) & Description \\
\hline 1 -hour & $<0.25$ & needles and twigs \\
\hline 10 -hour & $0.25-1$ & twigs, stems, small branches \\
\hline 100 -hour & $1-3$ & branches and stems \\
\hline 1000 -hour & $3-8$ & small logs and limbs \\
\hline$>1000$-hour & $>8$ & larger logs and limbs \\
\hline litter & N/A* & $\begin{array}{l}\text { identifiable plant parts, such as needles and twigs, on the forest } \\
\text { floor; typically behaves like 1-hour fuels }\end{array}$ \\
\hline duff & N/A & $\begin{array}{l}\text { more decomposed plant parts beneath the litter; typically behaves } \\
\text { like 1000-hour fuels }\end{array}$ \\
\hline
\end{tabular}


classes combined) in the eight Sierra Nevada monitoring sites ranged from 45 to 203 tons per acre in 2017, exceeding 100 tons per acre at three sites, with an average of 94 tons per acre. These total fuel loads are extremely high, and will increase in the future as standing dead trees begin to fall (Axelson et al. 2018). Management strategies for large and fine fuels are discussed below.

\section{AFTER TREE MORTALITY, FUEL MANAGEMENT TO REDUCE FIRE RISK}

Many factors determine fire risk, but fuel reduction can decrease the probability of an intense burn under a range of weather conditions (Safford et al. 2012). Many fuel reduction techniques are available, targeting different types of fuels.

During or soon after a tree mortality event, surveying the extent of damage and assessing fuel loads are important steps in planning a management approach and implementing it in a timely way. If landowners determine that they want to remove standing dead trees based on this assessment, perhaps because of the future hazard they pose to structures and/or increasing fuel loads, then removing them while they are standing snags (that is, mechanically felling them) is safer and less expensive than waiting for them to fall on their own; this is because felling trees allows landowners to control when and where they fall. In addition, dead trees are easier to sell as timber or biomass if they are removed quicklythough processing facilities for these wood products are scarce in the Sierra Nevada. In contrast, if only fine or surface fuels are to be treated, it may be most effective to wait until needles have fallen from dead trees and understory shrubs have started to grow. In either case, fuel treatments may need to be implemented before large snags begin to fall and endanger management crews. Unfortunately, fuel reduction treatments are typically expensive to implement. Financial, technical, or cost-share assistance may be available to landowners to implement fuel treatments, for example through Cal Fire and the Natural Resources Conservation Service (see appendix B).

Management actions can include masticating or burning surface and ladder fuels, felling and removing dying and dead standing trees, and thinning live trees. Large snags provide important wildlife habitat, so some of these dead trees should be retained if they will not damage infrastructure when they fall and are not surrounded by ladder fuels. Whether or not tree die-offs have occurred, targeted combinations of planting, thinning, and burning may be needed to make future forests less dense-as well as more diverse and complex with respect to tree species and sizes and less likely than premortality forests to burn catastrophically (Kalies and Yocom Kent 2016; North et al. 2019; Stephens et al. 2018).

\section{Prescribed fire}

Intentional, controlled burning is often the most effective means to decrease fuel loads and future risk from fires (Kalies and Yocom Kent 2016; Schwilk et al. 2009). Prescribed burns require careful planning and preparation, as well as permits. Fuels that are burned under favorable conditions in the winter, spring, or fall will not be available to burn under severe fire weather conditions. Several burning methods are possible. Fuels can be piled by hand or with machinery prior to burning. This method can help remove larger fuels, such as pieces of logs. Piles must be smaller than four feet in height and diameter to limit the risk of fire escape, as well as to comply with state regulations, and should ideally be placed outside the canopy of remaining trees to avoid damaging or igniting them. A Cal Fire permit is required to burn during fire season, and burns may be conducted only on burn days designated by the local air quality district. Before burning, landowners must consult their local air districts to determine whether burning is allowed that day. If a large amount of fuel will be burned, landowners may also need to develop smoke management plans.

In broadcast burning (fig. 11), fire is allowed to spread through surface fuels throughout a stand. The boundary of the area to be burned must be cleared of all fuels, down to the bare soil, to contain the fire. Broadcast burns are designed to mimic natural surface fires and are typically larger in area than pile burns. They may be designed to kill small trees and shrubs in addition to burning both fine and large dead fuels. Broadcast burns have many ecological benefits and may help move California's forests closer to the ecological conditions to which they are adapted. Potentially, they may also reduce stresses that will be placed on forests as the climate changes and conditions diverge from those of the past. As climate change continues, landowners and managers will need to be flexible in designing treatments if the 


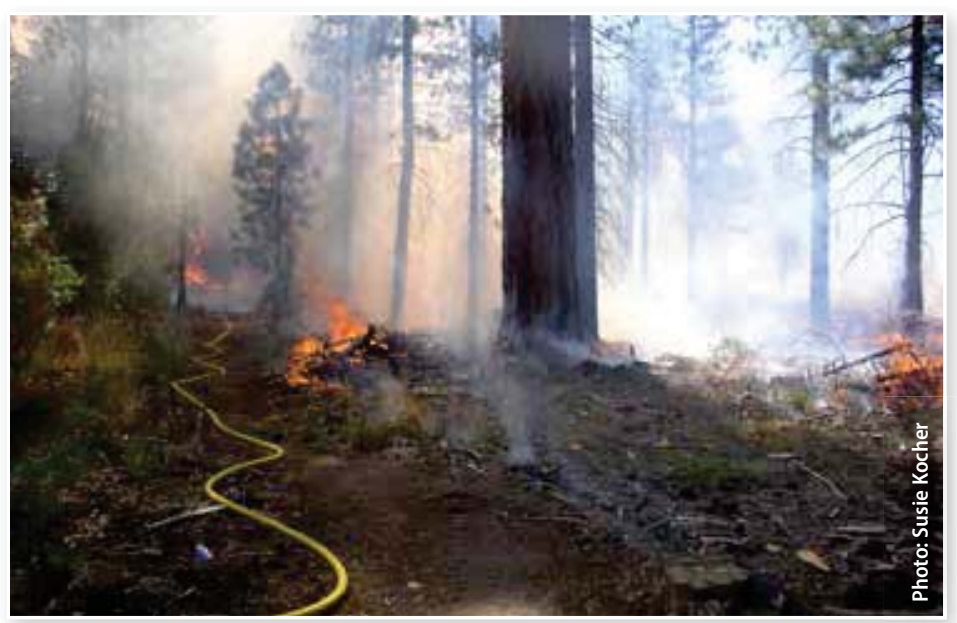

Figure 11. A prescribed fire of low severity is consuming understory plants and branches on the forest floor but leaving the mature trees intact. Note the fuel break around the fire, where fuels are removed down to the bare soil.

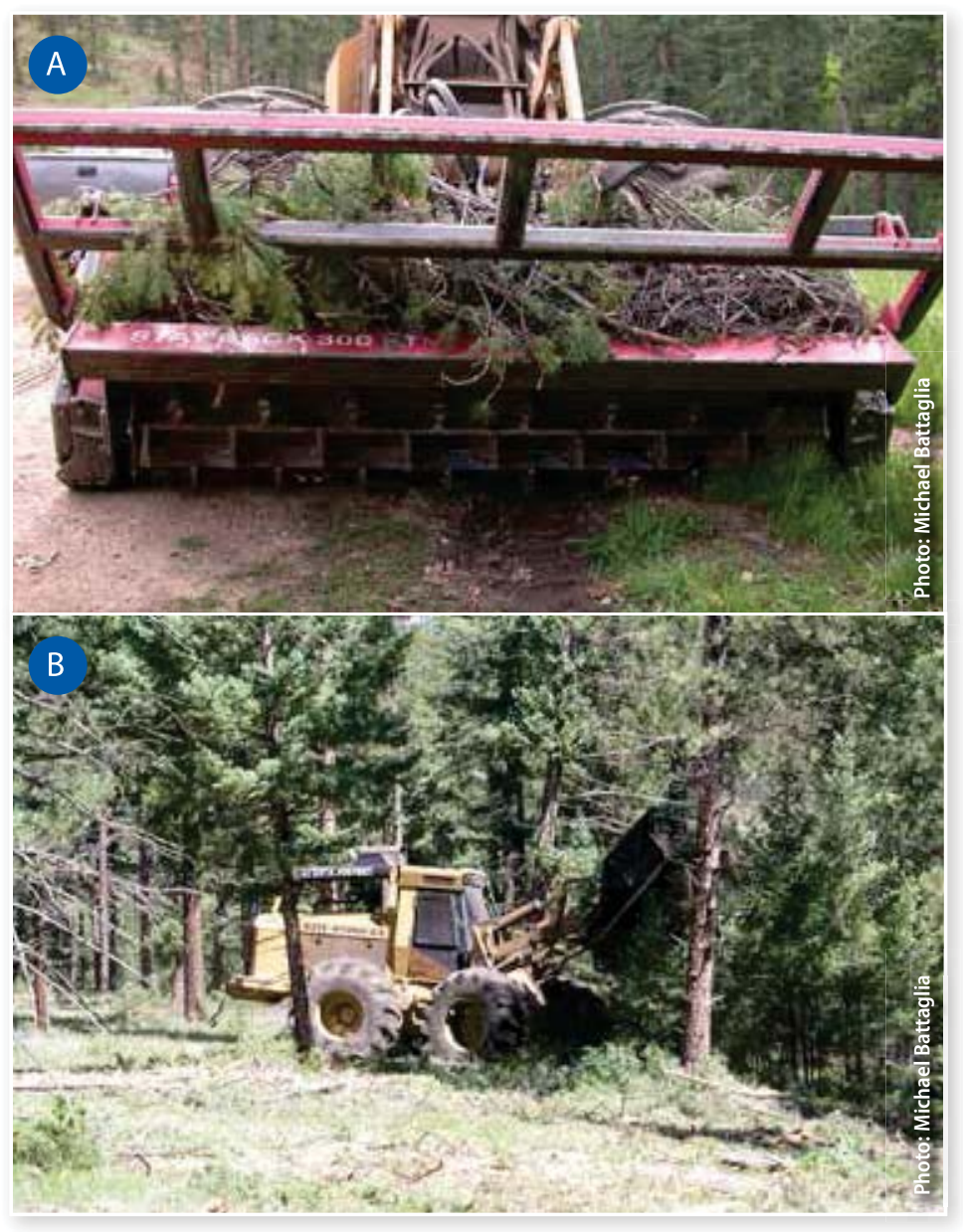

Figure 12. Mastication heads can be mounted on wheeled and tracked machinery. Many styles are available for treating brush and small trees. A masticator head is mounted on a wheeled skidder (A). The masticator head is being lowered onto small trees to shred them (B). historical forest composition (for example, species and space between trees) is not well adapted to new conditions.

Landowners have several options for burning. Landowners may be able to carry out burns themselves during very low-risk weather conditions, such as sometimes exist during the winter. Neighbors can form a formal or informal prescribed burn association to assist one another. For more complex projects, landowners or associations may be able to hire a qualified burn boss to assume liability for the burn and implement it. Or they may be able to sign up with Cal Fire's Vegetation Management Program if the size and location of a property qualifies it as a high-priority area. Prescribed fire policy and resources are changing rapidly, so checking on current status is advised. Prescribed fire councilslocal advocacy groups that promote the safe use of prescribed fire-may be good contacts for finding such information, as are local forestry advisors from the University of California Agriculture and Natural Resources Division (UC ANR; see appendix B).

\section{Mastication}

Mastication involves using specialized equipment to chew brush and branches into chips and leave them distributed on the forest floor (fig. 12). This technique removes ladder fuels, creates a continuous layer of surface fuels to carry a prescribed fire, and speeds decomposition by breaking fuels into small pieces and keeping them in contact with moist soil. In the short term, however, mastication does not remove surface fuels unless it is combined with prescribed fire, and the continuous fuel bed resulting from mastication can increase fire risk for a year or two after treatment (De Lasaux and Kocher 2006). It may also be difficult to burn masticated material, depending on the weather conditions.

\section{Dead tree removal}

Snags provide habitat for a variety of species, but can also become hazardous as they decay and fall. Targeted removal of snags that threaten people or homes, and increase potential fire intensity in vulnerable areas, may be an important component of risk management. Removing dead trees over large areas can remove a significant amount of the large fuels at a site-and can reduce the risk of mass fires and of smoldering fires that kill roots and change the chemical properties of soils. Key to this strategy is to remove trees as soon as possible, while they can be 
felled safely and the wood may still be merchantable. For further risk reduction, it is important to treatthrough prescribed fire or mastication-fine fuels left behind after tree removal.

Dead trees should be removed by certified professionals. If the forest owner sells or trades any of the wood removed, the work is subject to regulation by Cal Fire, and the landowner will need to work with a registered professional forester to file a Timber Harvest Plan or emergency exemption. Tree removal or pruning may also require hiring a licensed tree service contractor, even if no sale is involved. For example, the California Forest Improvement Program requires that a licensed tree service contractor be hired if trees more than 15 feet tall will be removed, or if the project costs more than $\$ 500$. Smaller projects can be performed by an arborist or certified tree feller.

\section{Mechanical thinning}

Bark beetle outbreaks often kill large trees that would otherwise be resistant to fire, leaving many smaller trees intact. These small trees may need additional thinning to improve their health, maintain an open stand structure, and limit fire severity (North et al. 2019). Even following tree mortality, many California forests are still unnaturally dense (Safford and Stevens 2017; Taylor et al. 2014), particularly in the northern Sierra, where tree mortality has been less severe (Ansley and Battles 1998; Axelson et al. 2018). In these dense forests, thinning of large or small trees may be necessary to reduce ladder fuels and separate tree crowns. Thinning can also, by reducing competition for water, help remaining trees survive and recover from droughts (Sohn et al. 2016; Vernon et al. 2018). Thinning can also reduce the severity of future fires, particularly when coupled with prescribed burning (Kalies and Yocom Kent 2016; Safford et al. 2012). As with postmortality fuels, the surface fuel created by thinning may need to be redistributed, burned, or masticated to limit fire risk.

\section{CONCLUSIONS}

Mass tree mortality has affected vast areas of forest in California, particularly in drier, lower-elevation areas, pine-dominated vegetation types, and the southern Sierra Nevada. Tree mortality has increased the amount of dead, dry fuel on the landscape and has increased the continuity of surface fuel. In addition to mortality-related fuels, many factors determine the risk of severe fire, including ignition sources, weather conditions, and density of live vegetation. Under some conditions, however, changes to fuel loads as a result of tree mortality may allow fires to burn more intensely, spread over larger areas, and cause more damage to forests. Carefully planned forest management can reduce the amount and continuity of fuel on the landscape and limit the risk of destructive fire after tree mortality.

\section{APPENDIX A: GLOSSARY}

Background mortality: Death rate of individual trees in the absence of a larger disturbance such as a severe drought, fire, or bark beetle outbreak.

Burn day: A day when the local air district has determined that local weather conditions allow for safe burning of fuels.

Crown fuel: Branches, needles, and other flammable material in the tree canopy.

Disturbance: An event that changes the structure of a forest by killing or damaging trees.

Fine fuel: Plant materials less than 3 inches in diameter (1-hour to 100-hour fuels), plus leaf litter.

Fire intensity: How much heat is released in a fire.

Fire severity: How much damage a fire inflicts on vegetation.

Fuel load: The amount of live and dead vegetation that is available to burn on a landscape.

Ladder fuel: Fuel such as shrubs, small trees, and low branches that can carry surface fires into the canopy.

Mass fire: A phenomenon in which areas measuring a square mile or more burn at once and create self-reinforcing wind patterns; can occur when fuel loads are very high.

Mass tree mortality: A discrete tree mortality event large and severe enough to suggest a shift away from historical mortality patterns.

Prescribed fire: Fire intentionally set to remove fuel and promote forest health.

Registered professional forester: A licensed professional who can help design and implement a forest management plan, including treatments such as thinning or prescribed burning. 
Risk (from fire): The product of ignition probability, expected fire intensity based on fuel load and fuel moisture, and a forest's vulnerability to that fire intensity.

Snag: A standing dead tree.

Spotting: A means of fire spread in which flying embers ignite fuel located ahead of a fire's advancing edge.

Surface fuel: Dead or live vegetation on the ground.

Type conversion: Transition from forest to shrubland or grassland (or the reverse). Type conversion can result from a change in the frequency of fires.

Uncharacteristic wildfire: A fire that is larger or more intense than the conditions to which forests are adapted.

\section{APPENDIX B: RESOURCES}

Links are current as of July 31, 2020. In case of broken links, an internet search for the terms in quotation marks, or those terms plus California or the name of a county, should retrieve the relevant information. Many resource pages are organized by county.

\section{General forest stewardship resources}

\section{"University of California Cooperative Extension" (UCCE) offices and advisors}

UCCE provide ways for land managers and communities to connect with information, best practices, and the latest research from UC programs. UCCE, with experts based in each county and on university campuses, is dedicated to serving local needs. Questions can be addressed to county advisors, listed on the "UC Agriculture and Natural Resources" website, https://ucanr.edu/About/Locations/.

UC ANR offers a variety of forestry classes, workshops, and publications, https://ucanr.edu/forestry/. Through the "Ask an Expert" form, https://ucanr.edu/ sites/forestry/Contact/ContactSurvey/, members of the public can submit forestry questions online.

Many UCCE publications are available through the publications link on the UC ANR Forestry website, https://ucanr.edu/sites/forestry/Publications/, or through the "UC ANR catalog," https://anrcatalog. ucanr.edu/ (many publications are free to download). Highly relevant publications include:
"Forest Stewardship Series 15, Wildfire and Fuel Management," UC ANR Publication 8245 (Nunamaker et al. 2007), https://anrcatalog.ucanr.edu/pdf/8245. pdf. The "Forest Stewardship Series" provides an overview of many aspects of forest management and includes additional resources and references.

UCCE Fuel Reduction Guide for Sierra Nevada Forest Landowners (De Lasaux and Kocher 2006), https://www.plumasfiresafe.org/ uploads/8/1/8/4/81849812/fuel_reduction_guide_ for_sierra_nevada_forest_landowners.pdf. This 2006 guide (no longer available through UC ANR) contains useful details on multiple fuel management techniques, though its cost estimates for fuel treatments are out of date.

UC ANR also provides publications and offers a variety of information about workshops and fire risk reduction, https://ucanr.edu/fire/. Through the "Ask an Expert" form, https://ucanr.edu/sites/fire/ Contact/, members of the public can submit fire questions online.

\section{"California Resource Conservation Districts" (RCDs)}

RCDs are local agencies that provide information and technical and financial assistance for land and resource management, including forest stewardship and fuels management. There are ninety-eight RCDs in California, grouped into ten regions.

The "California Association of Resource Conservation Districts" maintains a catalog of RCD contact information organized by region, https://carcd.org/ rcds/find/.

The association can also be reached by phone at (916) 457-7904.

All 98 RCDs are listed on the "Department of Conservation" website, https://www.conservation. ca.gov/dlrp/RCD/Pages/CaliforniaRCDs.aspx, with links to the web pages of most RCDs.

\section{"Natural Resources Conservation Service" (NRCS)}

NRCS is a branch of the U.S. Department of Agriculture, with expertise in other aspects of land management as well. NRCS offices can provide technical and financial assistance for conservation-related projects through initiatives such as the Conservation Stewardship Program and the Environmental Quality Incentives Program. Contact information for each county's offices is available from the "NRCS Service Center Locator" or the contact tab on the NRCS home page, https://www.nrcs.usda.gov. 


\section{Fuels treatment resources}

"Fuel load photo series"

Photos of various fuel loads in certain ecosystems may be used to calibrate visual estimation of fuel loads and assess whether fuel treatments may be necessary. A good photo resource is the U.S. Forest Service publication "Photo Series for Quantifying Natural Forest Residues: Southern Cascades, Northern Sierra Nevada" (Blonski and Schramel 1981, https://doi.org/10.2737/PSW-GTR-56).

Many forest ecosystems outside the Sierra Nevada, including pinyon-juniper and sagebrush systems, are included in the "Natural Fuels Photo Series." This publication, also produced by the Forest Service, is available in digital form, https://depts.washington. edu/nwfire/dps/; additional information is likewise available, https://www.fs.fed.us/pnw/fera/research/ fuels/photo_series/.

\section{Tree removal}

\section{"Registered professional foresters"}

Registered professional foresters are licensed in California to assess forest health and potential problems and, in compliance with California's Forest Practice Act, to plan and implement forest management activities such as thinning.

The "California Board of Forestry" maintains a "roster of consulting professional foresters," https://bof.fire.ca.gov/projects-and-programs/ professional-foresters-registration/rpfcrm-rosters/.

The "Society of American Foresters" also lists a smaller selection of "certified professional foresters," https://www.eforester.org/Main/Certification_Education/Certified_Forester/Find_a_Certified_Professional/Main/Certification/Find_a_Certified_Professional. aspx.

\section{Tree removal specialists}

Thinning or snag removal projects in California may require a licensed "tree service contractor." These contractors are approved by the "California Contractors State License Board" as limited specialty contractors (class C-61/D-49), and their licenses can be verified at the CSLB website, http://www.cslb.ca.gov/ Consumers/.

California also certifies "licensed timber operators" who can fell and remove trees, including for wood sales.

\section{Burning}

"Prescribed fire councils"

Prescribed fire councils may be able to suggest resources for safely and effectively using fire to remove fuels.

- "Northern California Prescribed Fire Council," http://www.norcalrxfirecouncil.org/home.html.

- “Southern Sierra Prescribed Fire Council," https:// sites.google.com/site/sosierrapfc/.

- “Central Coast Prescribed Fire Council," http:// www.centralcoastrxfirecouncil.org/.

Other resources relevant to prescribed fire include the "Fire Research and Management Exchange System" (FRAMES), which offers extensive information on fire and fuel management, including the video series "World of Wildland Fire," https://www.frames. gov/worldofwildlandfire/home.

The "California Prescribed Burn Alliance," http:// calpba.org/, provides an overview of prescribed burn associations (PBAs) in California. PBAs are community-based, mutual-aid networks that help private landowners put "good fire" on their land.

\section{"California Air Districts"}

California Air Districts are responsible for determining whether burning on private property is acceptable on a given day, based on whether burning would likely degrade air quality beyond acceptable thresholds.

A "local air district directory," including contact phone numbers, is available from the "California Air Resources Board," https://www.arb.ca.gov/capcoa/roster.htm-along with a map with links to the various air district websites, which may include additional information on burn permits specific to air districts, https://www.arb.ca.gov/capcoa/dismap.htm.

\section{"Cal Fire"}

Cal Fire is responsible for managing wildfires in California, as well as regulation of harvesting, burning, and other forest management activities. Cal Fire's website, https://www.fire.ca.gov/, includes a wealth of information on fire safety, fire risk reduction, and timber harvesting.

Cal Fire "burn permits" for some counties can be obtained online, https://burnpermit.fire.ca.gov/; the process involves watching a short fire safety video and filling out a form. Burn permits can also be obtained from a local Cal Fire station. Contact information for local stations is available through 
Cal Fire units, https://www.fire.ca.gov/resources/ cal-fire-contacts/.

Some counties and air districts have their own permitting processes, separate from Cal Fire, and may charge a fee for a burn permit. Even with a permit, landowners must contact their local air districts before burning to verify that the day on which they wish to burn is a burn day. More information regarding prescribed fire and permitting can be obtained online from UCCE, https://ucanr.edu/sites/fire/ RXFire/Permits/.

For each "Cal Fire administrative unit," updates on "burn status" - that is, whether burning is restricted for the season-are available online, https://burnpermit.fire.ca.gov/current-burn-status/. Even after landowners check on burn status, they still must check with the local air districts before burning.

Cal Fire's "Fire and Resource Assessment Program" has produced a map of tree mortality and fire hazard in California, http://egis.fire.ca.gov/TreeMortalityViewer/. The map also shows areas assessed to be at risk of bark beetle attacks, current biomass processing plants, fire perimeters, and other spatial information related to tree mortality and fire risk that may be useful in planning.

Cost-sharing programs are also available through Cal Fire, including the "California Forest Improvement Program." This program, https://www.fire. ca.gov/grants/california-forest-improvement-program-cfip/, helps land managers cover the costs of thinning, replanting, and other projects to improve forest health.

\section{"Wildland Fire Assessment System"}

The Wildland Fire Assessment System (WFAS) provides information on fuel moisture and fire weather conditions.

The WFAS, operated by the U.S. Forest Service, produces up-to-date coarse-scale maps of "fire danger rating," based on current and recent weather, vegetation types, and fuel moisture measured at weather stations and extrapolated across the United States. Maps of current and forecast fire danger (low, moderate, high, very high, or extreme) for the United States and specific regions are available, https://www.wfas. net/).

\section{Forest data sources}

"Forest Inventory and Analysis" data are collected across public and private forested lands of the United
States on a roughly 10 -year revisit cycle, providing a metric of large-scale forest trends. Several visualization tools are available, https://www.fia.fs.fed.us/ tools-data/.

Reports produced under Assembly Bill 1504 ("California Forest Ecosystem and Harvested Wood Product Carbon Inventory”) include detailed tables regarding carbon stocks and changes in forest regions and ownerships in California. These reports, https://www.oregon.gov/ODF/Board/Documents/ BOF/20180606/BOFATTCH_20180606_02_01.pdf, may be useful in applying for grants.

Many forest-related publications are available through Treesearch, the U.S. Forest Service database, https://www.fs.usda.gov/treesearch/.

\section{ACKNOWLEDGMENTS}

Figure 4, from the Wieslander Vegetation Type Mapping collection, appears courtesy of the Marian Koshland Bioscience, Natural Resources, and Public Health Library at UC Berkeley.

\section{REFERENCES}

Agee, J. K., and C. N. Skinner. 2005. Basic principles of forest fuel reduction treatments. Forest Ecology and Management 211(1-2):83-96. https://doi. org/10.1016/j.foreco.2005.01.034

Agne, M. C., T. Woolley, and S. Fitzgerald. 2016. Fire severity and cumulative disturbance effects in the post-mountain pine beetle lodgepole pine forests of the Pole Creek Fire. Forest Ecology and Management 366:73-86. https://doi.org/10.1016/j. foreco.2016.02.004

Allen, C. D., D. D. Breshears, and N. G. McDowell. 2015. On underestimation of global vulnerability to tree mortality and forest die-off from hotter drought in the Anthropocene. Ecosphere 6(8):129. https://doi. org/10.1890/ES15-00203.1

Allen, C. D., A. K. Macalady, H. Chenchouni, D. Bachelet, N. McDowell, M. Vennetier, T. Kitzberger, A. Rigling, D. D. Breshears, E. H. Hogg, P. Gonzalez, R. Fensham, Z. Zhang, J. Castro, N. Demidova, J. H. Lim, G. Allard, S. W. Running, A. Semerci, and N. Cobb. 2010. A global overview of drought and heat-induced tree mortality reveals emerging climate change risks for forests. Forest Ecology and Management 259(4):660-684. https://doi. org/10.1016/j.foreco.2009.09.001 
Ansley, J. A. S., and J. J. Battles. 1998. Forest composition, structure, and change in an oldgrowth mixed conifer forest in the northern Sierra Nevada. The Journal of the Torrey Botanical Society 125(4):297-308. https://doi.org/10.2307/2997243

Axelson, J. N., J. Battles, B. Bulaon, D. Cluck, S. Cousins, L. Cox, B. Estes, C. Fettig, A. Hefty, S. Hishinuma, S. Hood, S. Kocher, D. McMahon, L. Mortenson, A. Koltunov, E. Kuskulis, A. Poloni, C. Ramirez, C. Restaino, H. Safford, M. Slaton, S. Smith, C. Tubbesing, R. Wayman, and D. Young. 2019. The California Tree Mortality Data Collection Network - Enhanced communication and collaboration among scientists and stakeholders. California Agriculture. 73(2):55-62. https://doi.org/10.3733/ ca.2019a0001

Axelson, J., J. Battles, L. Cox, S. Kocher, and E. Kuskulis. 2018. Massive tree mortality in the Sierra Nevada: Consequences for forest health, carbon storage and wildfire hazard. Presented at Tree Mortality Data Collection Network Workshop, Mar. 12, McClellan, CA.

Axelson, J., J. Battles, A. Das, and P. van Mantgem. 2019. Coming to terms with the new normal: Forest resilience and mortality in the Sierra Nevada. Fremontia 46(3):50-56.

Battles, J. J., S. J. M. Cousins, and J. E. Sanders. 2015. Carbon dynamics and greenhouse gas emissions of standing dead trees in California mixed conifer forests. California Energy Commission Publication CEC-500-2016-001. https://pdfs.semanticscholar. org/16ab/02cf6339a9f9b6062140edd07e53a33f34bd. pdf

Bigler, C., D. Kulakowski, and T. T. Veblen. 2005. Multiple disturbance interactions and drought influence fire severity in Rocky Mountain subalpine forests. Ecology 86(11):3018-3029. https://doi. org/10.1890/05-0011

Blonski, K. S., and J. L. Schramel. 1981. Photo series for quantifying natural forest residues: Southern Cascades, Northern Sierra Nevada. Berkeley: U.S. Department of Agriculture. https://doi.org/10.2737/ PSW-GTR-56

Bond, M. L., D. E. Lee, C. M. Bradley, and C. T Hanson. 2009. Influence of pre-fire tree mortality on fire severity in conifer forests of the San Bernardino Mountains, California. The Open Forest Science Journal 2:41-47.

Brown, J. K. Handbook for inventorying downed woody material. 1974. General Technical Report INT-16. Ogden, UT: U.S. Forest Service, Intermountain Forest and Range Experiment Station. https://www. fs.usda.gov/treesearch/pubs/28647
Christensen, G. A., A. N. Gray, O. Kuegler, N. A. Tase, and M. Rosenberg. 2018. AB 1504 California Forest Ecosystem and Harvested Wood Product Carbon Inventory: 2006-2015. Final Report. 390. Sacramento, CA: California Department of Forestry and Fire Protection.

Coppoletta, M., K. E. Merriam, B. M. Collins. 2016. Post-fire vegetation and fuel development influences fire severity patterns in reburns. Ecological Applications 26(3):686-699. https://doi. org/10.1890/15-0225

Das, A. J., N. L. Stephenson, and K. P. Davis. 2016. Why do trees die? Characterizing the drivers of background tree mortality. Ecology 97(10):26162627. https://doi.org/10.1002/ecy.1497

De Lasaux, M., and S. D. Kocher. 2006. Fuel reduction guide for Sierra Nevada Forest landowners. UC Agriculture and Natural Resources. http:// cecentralsierra.ucanr.edu/files/88262.pdf

Fettig, C. J., S. R. McKelvey, D. R. Cluck, S. L. Smith, and W. J. Otrosina. 2010. Effects of prescribed fire and season of burn on direct and indirect levels of tree mortality in Ponderosa and Jeffrey Pine forests in California, USA. Forest Ecology and Management 260(2):207-218. https://doi.org/10.1016/j. foreco.2010.04.019

Fettig, C. J., L. A. Mortenson, B. M. Bulaon, and P. B. Foulk. 2019. Tree mortality following drought in the central and southern Sierra Nevada, California. U.S. Forest Ecology and Management 432:164-178. https://doi.org/10.1016/j.foreco.2018.09.006

Finney, M. A. 2005. The challenge of quantitative risk analysis for wildland fire. Forest Ecology and Management 211(1-2):97-108. https://doi. org/10.1016/j.foreco.2005.02.010

Hardy, C. C. 2005. Wildland fire hazard and risk: Problems, definitions, and context. Forest Ecology and Management 211(1-2):73-82. https://doi. org/10.1016/j.foreco.2005.01.029

Hart, S. J., T. Schoennagel, T. T. Veblen, and T. B. Chapman. 2015. Area burned in the western United States is unaffected by recent mountain pine beetle outbreaks. Proceedings of the National Academy of Sciences 112(14):4375-4380. https://doi.org/10.1073/ pnas. 1424037112

Hicke, J. A., M. C. Johnson, J. L. Hayes, and H. K. Preisler. 2012. Effects of bark beetle-caused tree mortality on wildfire. Forest Ecology and Management 271:81-90. https://doi.org/10.1016/j. foreco.2012.02.005 
Jenkins, M. J., W. G. Page, E. G. Hebertson, and M. E. Alexander. 2012. Fuels and fire behavior dynamics in bark beetle-attacked forests in Western North America and implications for fire management. Forest Ecology and Management 275:23-34. https:// doi.org/10.1016/j.foreco.2012.02.036

Jolly, W. M., R. A. Parsons, A. M. Hadlow, G. M. Cohn, S. S. McAllister, J. B. Popp, R. M. Hubbard, and J. F. Negron. 2012. Relationships between moisture, chemistry, and ignition of Pinus contorta needles during the early stages of mountain pine beetle attack. Forest Ecology and Management 269:52-59. https://doi.org/10.1016/j.foreco.2011.12.022

Kalies, E. L., and L. L. Yocom Kent. 2016. Are fuel treatments effective at achieving ecological and social objectives? A systematic review. Forest Ecology and Management 375:84-95. https://doi. org/10.1016/j.foreco.2016.05.021

Keeley, J. E. 2009. Fire intensity, fire severity and burn severity: a brief review and suggested usage. International Journal of Wildland Fire 18(1):116126. https://doi.org/10.1071/WF07049

Keeley, J. E., and A. D. Syphard. 2018. Historical patterns of wildfire ignition sources in California ecosystems. International Journal of Wildland Fire 27(12):781-799. https://doi.org/10.1071/WF18026

Lutes, D. C., R. E. Keane, J. F. Caratti, C. H. Key, N. C. Benson, S. Sutherland, and L. J. Gangi. 2006. FIREMON: Fire effects monitoring and inventory system. Fort Collins, CO: U.S. Department of Agriculture. https://doi.org/10.2737/RMRS-GTR-164

Monsanto, P. G., and J. K. Agee. 2008. Long-term postwildfire dynamics of coarse woody debris after salvage logging and implications for soil heating in dry forests of the eastern Cascades, Washington. Forest Ecology and Management 255(12):3952-3961. https://doi.org/10.1016/j.foreco.2008.03.048

Moore, J., J. Pope, M. Woods, and A. Elli. 2019. 2018 Aerial Survey Results: California. Davis, CA: Forest Health Monitoring Program. https://www.fs.usda. gov/Internet/FSE_DOCUMENTS/fseprd657096.pdf

Nagel, T. A., and A. H. Taylor. 2005. Fire and persistence of montane chaparral in mixed conifer forest landscapes in the northern Sierra Nevada, Lake Tahoe Basin, California, USA. The Journal of the Torrey Botanical Society 132(3):442-457. https:// www.jstor.org/stable/20063784
North, M. P., J. T. Stevens, D. F. Greene, M. Coppoletta, E. E. Knapp, A. M. Latimer, C. M. Restaino, R. E. Tompkins, K. R. Welch, R. A. York, D. J. N. Young, J. N. Axelson, T. N. Buckley, B. L. Estes, R. N. Hager, J. W. Long, M. D. Meyer, S. M. Ostoja, H. D. Safford, K. L. Shive, C. L. Tubbesing, H. Vice, D. Walsh, C. M. Werner, and P. Wyrsch. 2019. Tamm Review: Reforestation for resilience in dry western U.S. forests. Forest Ecology and Management 432:209224. https://doi.org/10.1016/j.foreco.2018.09.007

Nunamaker, C., M. De Lasaux, and G. Nakamura, G. 2007. Forest Stewardship Series 15: Wildfire and fuel management. Oakland: UC Agriculture and Natural Resources Publication 8245. https://anrcatalog.ucanr. edu/pdf/8245.pdf

Page, W. G., and M. J. Jenkins. 2007. Mountain pine beetle-induced changes to selected lodgepole pine fuel complexes within the intermountain region. Forest Science 53(4):507-518. https:// digitalcommons.usu.edu/cgi/viewcontent. cgi ?article $=1103 \&$ context $=$ barkbeetles

Page, W. G., M. J. Jenkins, and J. B. Runyon. 2012. Mountain pine beetle attack alters the chemistry and flammability of lodgepole pine foliage. Canadian Journal of Forest Research 42(8):1631-1647. https:// doi.org/10.1139/x2012-094

Paz-Kagan, T., P. G. Brodrick, N. R. Vaughn, A. J. Das, N. L. Stephenson, K. R. Nydick, and G. P. Asner. 2017. What mediates tree mortality during drought in the southern Sierra Nevada? Ecological Applications 27(8):2443-2457. https://doi. org/10.1002/eap.1620

Pile, L. S., M. D. Meyer, R. Rojas, and O. Roe. 2018. Characterizing tree mortality after extreme drought and insect outbreaks in the southern Sierra Nevada. In J. E. Kirschman, ed., Proceedings of the 19th biennial southern silvicultural research conference, Asheville, NC.

Safford, H. D., and J. T. Stevens. 2017. Natural range of variation for yellow pine and mixed-conifer forests in the Sierra Nevada, southern Cascades, and Modoc and Inyo National Forests, California, USA. Albany, CA: U.S. Department of Agriculture General Technical Report PSW-GTR-256. https://www. fs.fed.us/psw/publications/documents/psw_gtr256/ psw_gtr256.pdf

Safford, H. D., J. T. Stevens, K. Merriam, M. D. Meyer, and A. M. Latimer. 2012. Fuel treatment effectiveness in California yellow pine and mixed conifer forests. Forest Ecology and Management 274:17-28. https:// doi.org/10.1016/j.foreco.2012.02.013 
Schwilk, D. W., J. E. Keeley, E. E. Knapp, J. McIver, J. D. Bailey, C. J. Fettig, C. E. Fiedler, R. J. Harrod, J. J. Moghaddas, K. W. Outcalt, C. N. Skinner, S. L. Stephens, T. A. Waldrop, D. A. Yaussy, and A. Youngblood. 2009. The national fire and fire surrogate study: effects of fuel reduction methods on forest vegetation structure and fuels. Ecological Applications 19(2):285-304. https://doi. org/10.1890/07-1747.1

Scott, J. H., M. P. Thompson, and D. E. Calkin. 2013. A wildfire risk assessment framework for land and resource management. U.S. Forest Service General Technical Report RMRS-GTR-315. https://doi. org/10.2737/rmrs-gtr-315

Sohn, J. A., S. Saha, and J. Bauhus. 2016. Potential of forest thinning to mitigate drought stress: A metaanalysis. Forest Ecology and Management 380:261273. https://doi.org/10.1016/j.foreco.2016.07.046

Stephens, S. L., B. M. Collins, C. J. Fettig, M. A. Finney, C. M. Hoffman, E. E. Knapp, M. P. North, H. Safford, and R. B. Wayman. 2018. Drought, tree mortality, and wildfire in forests adapted to frequent fire. BioScience 68(2):77-88. https://doi.org/10.1093/ biosci/bix146

Stephenson, N. L., A. J. Das, N. J. Ampersee, B. M. Bulaon, and J. L. Yee. 2019. Which trees die during drought? The key role of insect host-tree selection. Journal of Ecology 107(5):2383-2401. https://doi. org/10.1111/1365-2745.13176
Taylor, A. H., A. M. Vandervlugt, R. S. Maxwell, R. M. Beaty, C. Airey, and C. N. Skinner. 2014. Changes in forest structure, fuels and potential fire behaviour since 1873 in the Lake Tahoe Basin, USA. Applied Vegetation Science 17:17-31. https://onlinelibrary. wiley.com/doi/abs/10.1111/avsc.12049

Van Mantgem, P. J., D. A. Falk, E. C. Williams, A. J. Das, and N. L. Stephenson. 2018. Pre-fire drought and competition mediate post-fire conifer mortality in western U.S. National Parks. Ecological Applications 28(7):1730-1739. https://doi.org/10.1002/eap.1778

Van Mantgem, P. J., N. L. Stephenson, J. C. Byrne, L. D. Daniels, J. F. Franklin, P. Z. Fulé, M. E. Harmon, A. J. Larson, J. M. Smith, A. H. Taylor, and T. T. Veblen. 2009. Widespread increase of tree mortality rates in the western United States. Science 323(5913):521524. https://doi.org/10.1126/science. 1165000

Vernon, M. J., R. L. Sherriff, P. van Mantgem, and J. M. Kane. 2018. Thinning, tree-growth, and resistance to multi-year drought in a mixed-conifer forest of Northern California. Forest Ecology and Management 422:190-198. https://doi.org/10.1016/j. foreco.2018.03.043

Walker, R. B., J. D. Coop, S. A. Parks, and L. Trader. 2018. Fire regimes approaching historic norms reduce wildfire-facilitated conversion from forest to non-forest. Ecosphere 9(4). https://doi.org/10.1002/ ecs2.2182

Young, D. J. N., J. T. Stevens, J. M. Earles, J. Moore, A. Ellis, A. L. Jirka, and A. M. Latimer. 2017. Long-term climate and competition explain forest mortality patterns under extreme drought. Ecology Letters 20:78-86. https://doi.org/10.1111/ele.12711 
To order or obtain UC ANR publications and other products, visit the UC ANR online catalog at https://anrcatalog.ucanr.edu/ or phone 1-800-994-8849. Direct inquiries to

UC Agriculture and Natural Resources

Publishing

2801 Second Street

Davis, CA 95618

Telephone 1-800-994-8849

E-mail: anrcatalog@ucanr.edu

(C)2020 The Regents of the University of California. This work is licensed under the Creative Commons Attribution-NonCommercialNoDerivatives 4.0 International License. To view a copy of this license, visit https://creativecommons.org/licenses/by-nc-nd/4.0/ or send a letter to Creative Commons, PO Box 1866, Mountain View, CA 94042, USA.

Publication 8683

ISBN-13: 978-1-62711-141-6

https://doi.org/10.3733/ucanr.8683

The University of California, Division of Agriculture and Natural Resources (UC ANR) prohibits discrimination against or harassment of any person in any of its programs or activities on the basis of race, color, national origin, religion, sex, gender, gender expression, gender identity, pregnancy (which includes pregnancy, childbirth, and medical conditions related to pregnancy or childbirth), physical or mental disability, medical condition (cancer-related or genetic characteristics), genetic information (including family medical history), ancestry, marital status, age, sexual orientation, citizenship, status as a protected veteran or service in the uniformed services (as defined by the Uniformed Services Employment and Reemployment Rights Act of 1994 [USERRA]), as well as state military and naval service.
UC ANR policy prohibits retaliation against any employee or person in any of its programs or activities for bringing a complaint of discrimination or harassment. UC ANR policy also prohibits retaliation against a person who assists someone with a complaint of discrimination or harassment, or participates in any manner in an investigation or resolution of a complaint of discrimination or harassment. Retaliation includes threats, intimidation, reprisals, and/or adverse actions related to any of its programs or activities.

UC ANR is an Equal Opportunity/Affirmative Action Employer. All qualified applicants will receive consideration for employment and/or participation in any of its programs or activities without regard to race, color, religion, sex, national origin, disability, age or protected veteran status.

University policy is intended to be consistent with the provisions of applicable State and Federal laws.

Inquiries regarding the University's equal employment opportunity policies may be directed to: Affirmative Action Compliance and Title IX Officer, University of California, Agriculture and Natural Resources, 2801 Second Street, Davis, CA 95618, (530) 750-1343. Email: titleixdiscrimination@ucanr.edu. Website: https://ucanr.edu/sites/ anrstaff/Diversity/Affirmative_Action/.

An electronic copy of this publication can be found at the UC ANR catalog website, http://anrcatalog.ucanr.edu/.

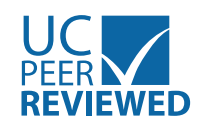

This publication has been anonymously peer reviewed for technical accuracy by University of California scientists and other qualified professionals. This review process was managed by UC ANR Associate Editor for Natural, Marine, and Freshwater Resources William C. Stewart.

web-8/20-LC/SO 